\title{
北海道と文学 (諩演要旨)
}

\section{和 田謹 吾*}

たまたま今年上半期の芥川賞受賞作が最近に決定 されて，それに北海道在住作家が入選したので，そ こから話の緒を引き出したい。

北海道出身作家, あるいは北海道に取材した作品 が芥川賞を受賞することは，これまで比較的少なか った。が，その少ない中に顕著な特徴があり，それ が過去の北海道の文学状沉を考兄るのに有効な手掛 かりになると思う。その特徴とはどういらことかと 言觉ば, 受賞は汪とんど終戦までに集中し, その素 材は北海道, 満洲などいわゆるく北方>るのであっ た。そして, 戦後には全く受賞作が出なかった。こ の事実はなにを物語るか。

昭和10年代の日本には，国策として満蒙開拓とい うことがあった。そしてそれらの地域は極寒の北方 地帯にあった。だから，それに通ずる国内の問題と して北海道の開拓といら問題意識があった。それ は，島木健作の『風のなか』といら作品などにも， 北海道の開拓がそのまま満蒙開拓に接続する扱いが あることによっても証明できる。それに加えて, 昭 和初期に活発な動きを見せたプロレタリア文学が, 10年代に入って現実批判が不可能になった時, 素材 を過去に求めて北海道開拓初期の父祖の歴史の中に 間接的に問題意識を提起しょうとした本庄隆男の 『石狩川』などの成功もあって, 昭和 10 年代の北海 道ものは，〈北方開拓〉といら国策意識に添うふし があった。そういら中で扔のずから注目され，繁栄 するというふしがあった。受賞作の出た所以でもあ る。ところが，敗戦後にはそらいら意識が社会的に 全くなくなった。言って見れば，北海道の文学は問 題意識の目標を失った形となった。新しい戦後社会

\section{* 北海道大学教授}

の中で北海道をどう見据光るか。それは伝統のない 北海道にとって，あたかも零からの新たな出発のよ らなものであった。芥川賞作家が出なくなった理由 を私はその辺に見たいと思う。したがって，こんに ちその受賞作家が出たといらことは, 戦後社会の急 速な変貌の中で, 北海道の文学がようやく浮上する 契機を㨔んだといら意味で注目したいと思うのであ る。

話は芥川賞に絡んで昭和における北海道の文学状 況のことが先になってしまったが，話を戾して歴史 的に遡れば，この土地には早くからアイヌ文学があ った。しかしアイヌ民族は文字による記録を残さな かったし, 言語も異なるので, 現代北海道の文学 に, アイヌ文学を継承発展させたと見られるらしは なく, したがって現代北海道文学の歴史を遡れば, 明治初期以降約百年の歴史しかない。その中で, 北 海道の文化・文学の基礎を作った最初の功績は, や はり札幙農学校に認められるべきであるら。初期農 学校は, クラークの見識によって, 単なる農業術技 教育にとどまらず，広く人間的教養を高めることに 意を用いた。その結果, 優れた農学者を輩出したこ とは言うに及ばず，本筋を離れても新渡戸稲造・内 村鑑三などのような近代日本の思想史の背骨を形づ くるような人物を出したし, 文学の世界でもやがて 有島武郎を生むに至るのである。

だが，有島まで行く前に，もら一つ注意すべき現 象がある。開拓の当初, 北海道へ移住して来た人々 は農業開拓者を主として,きびしい自然の試鍊と戦 っていたから，彼等の中に文学的産物を求めること は困難であった。いきおい，北海道を文筆の上に載 せるのは, 来道した文学者の筆によるしかなかっ た。そらいら中で注目されるのは国木田独歩の来道 
であった。彼の北海道滞在はたかだか二週間 であ り，北海道を素材にした作品は『牛肉と馬鈴薯』 『空知川の岸辺』の二篇しかない。にも拘らず, こ の独歩の存在は, のちの北海道の文学的成長の上に 大きな意味をもっている。それは，独歩が北海道の 地理的な自然環境の本質を見事に捉えていたからで ある。だから，道内で移住者たちの第二世が文学に 関心を向け始めた時，独歩の文学にまず自分たちの 表現意欲を刺戟された。その系譜に属する文学の系 列がその後の北海道の文学の中には明らかに認めら れる。

しかし，独歩は旅人として北海道の自然を見たに 過ぎない。この土地に住み，きびしい開拓の歴史の 中で生きる人々にとって, 独歩の世界は北海道の明 るくロマンティックな一面でしかない。そこに有島 文学登場の意味があった。有島は北海道生活の基本 であった農業について專門的に勉強した農学士であ る。そして有島農場の経営を通して開拓農民の実態
をつぶさに知っていた。前後12年間の札幌生活の体 験もある。そういう基礎の上に書かれた『カインの 末裔』や『生れ出づる悩み』は, 道内の文学青年た ちにとって，まさに自分たちの声の代表であり，自 分たちの文学の典型と見えたに違いない。以後の北 海道の文学は, 圧倒的にこの北海道の歴史的社会環 境を見据觉た有島文学の影響を受けるようになる。 冒頭に触れたく北方開拓＞ものも，系譜をたどれば この系列の一つのヴァリエーションと見ることがで きる。

かくて, 過去の北海道と文学とのかかわりは, こ の独歩系の文学々有島系の文学々の消長の中にあっ た。しかし，そのような先達の影響の 歴史が終わ り，そこから自立して新しい北海道の状況の中で創 造を求められる戦後の北海道の文学は, いまきびし い試練の中にスタート台に立ったといらことができ よう。（終) 